\title{
Article
}

\section{Children of the Twins Early Development Study (CoTEDS): A Children-of-Twins Study}

\author{
Yasmin I. Ahmadzadeh ${ }^{1}$, Thalia C. Eley ${ }^{1}$, Robert Plomin ${ }^{1}$, Philip S. Dale ${ }^{2}$, Kathryn J. Lester ${ }^{3}$, Bonamy R. Oliver ${ }^{4}$, \\ Andrew McMillan ${ }^{1}$ and Tom A. McAdams ${ }^{1}$ \\ ${ }^{1}$ Social, Genetic and Developmental Psychiatry Centre, Institute of Psychiatry, Psychology \& Neuroscience, King's College London, London, UK, \\ ${ }^{2}$ Department of Speech and Hearing Sciences, University of New Mexico, Albuquerque, NM, USA, ${ }^{3}$ School of Psychology, University of Sussex, Brighton, UK and \\ ${ }^{4}$ Department of Psychology, Goldsmiths, University of London, London, UK
}

\begin{abstract}
The Children of the Twins Early Development Study (CoTEDS) is a new prospective children-of-twins study in the UK, designed to investigate intergenerational associations across child developmental stages. CoTEDS will enable research on genetic and environmental factors that underpin parent-child associations, with a focus on mental health and cognitive-related traits. Through CoTEDS, we will have a new lens to examine the roles that parents play in influencing child development, as well as the genetic and environmental factors that shape parenting behavior and experiences. Recruitment is ongoing from the sample of approximately 20,000 contactable adult twins who have been enrolled in the Twins Early Development Study (TEDS) since infancy. TEDS twins are invited to register all offspring to CoTEDS at birth, with 554 children registered as of May 2019. By recruiting the second generation of TEDS participants, CoTEDS will include information on adult twins and their offspring from infancy. Parent questionnaire-based data collection is now underway for 1- and 2-year-old CoTEDS infants, with further waves of data collection planned. Current data collection includes the following primary constructs: child mental health, temperament, language and cognitive development; parent mental health and social relationships; parenting behaviors and feelings; and other socioecological factors. Measurement tools have been selected with reference to existing genetically informative cohort studies to ensure overlap in phenotypes measured at corresponding stages of development. This built-in study overlap is intended to enable replication and triangulation of future analyses across samples and research designs. Here, we summarize study protocols and measurement procedures and describe future plans.
\end{abstract}

Keywords: Behavioral genetics; children-of-twins; families; longitudinal; offspring; parents

(Received 24 May 2019; accepted 3 July 2019; First Published online 9 September 2019)

To date, most genetically informative research examining the origin of human traits has relied on twin studies to derive heritability estimates and related statistics (e.g. Polderman et al., 2015). Twin studies are based on comparisons of monozygotic (MZ) and dizygotic (DZ) twins to decompose the etiology of individual differences into genetic, shared environment and nonshared environment components. In this way, twin studies are focused on identifying etiological influences that make twins in the same generation more similar or different to one another. While twin heritability estimates go some way toward explaining why traits run in families, within-generation studies miss some of the picture - because it is also of interest to understand the factors underlying correlations between generations.

Parents and children are similar to one another, to a degree, in almost all measurable traits. These include physical characteristics (e.g. Jaaskelainen et al., 2011), personality traits (e.g. Boutwell \& Beaver, 2010), psychopathology (e.g. Micco et al., 2009), cognitive ability (e.g. Bouchard \& McGue, 1981), educational attainment

Author for correspondence: Tom A. McAdams, Email: tom.mcadams@kcl.ac.uk Cite this article: Ahmadzadeh YI, Eley TC, Plomin R, Dale PS, Lester KJ, Oliver BR, McMillan A, and McAdams TA. (2019) Children of the Twins Early Development Study (CoTEDS): A Children-of-Twins Study. Twin Research and Human Genetics 22: 514-522, https://doi.org/10.1017/thg.2019.61 (e.g. Hertz et al., 2007) and observed behaviors, such as cigarette smoking (Chassin et al., 2008). Cross-trait correlations are also found between generations, for example, between parent substance use and child psychopathology (Vidal et al., 2012). Such parentchild associations may arise through one or more of the following possible mechanisms: (1) Parents may have a direct effect on their children, influencing offspring development in some way through their behavior. For example, parental affection may increase feelings of self-worth in their children (McAdams et al., 2017). (2) Children may inherit genetic variants associated with the parent and child traits of interest. For example, genetic factors associated with depression in parents have been found to manifest as conduct problems in adolescent offspring, partially accounting for the phenotypic association between the parent and child traits (Silberg et al., 2010). This is an example of passive gene-environment correlation, whereby the child's genotype is correlated with the environment in which they are reared (with their environment characterized by the parent's genetically influenced trait of interest; Plomin et al., 1977). Accounting for passive gene-environment correlation is of crucial importance in distinguishing possible causal effects of parent-child interactions from the effects of genetic relatedness. (3) Parents and children share their environments at various levels. They inhabit the same or overlapping 


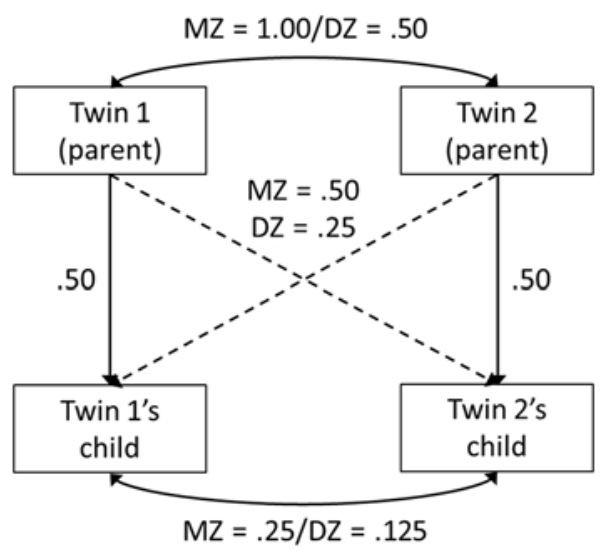

Fig. 1. Genetic correlations for monozygotic (MZ) and dizygotic (DZ) twin-pairs and their children. ${ }^{a}$

Note: ${ }^{a}$ Dashed lines show avuncular associations.

cultures, neighborhoods, extended families and nuclear families. Environmental influences operating at one or more of these levels can increase or induce correlations between parent and child traits. (4) Children may have a direct effect on their parents. For example, child anxiety symptoms can prospectively predict future anxiety symptoms in mothers (Ahmadzadeh et al., 2019); and children may influence the parenting that they receive (Avinun \& Knafo, 2014; Oliver et al., 2014).

While studies of twins and their parents can be useful in understanding the nature of associations between parent and child traits, they can only ever tell us about the role of offspring genes in these associations because we only have information on the relatedness between people within the offspring generation (the twins' generation). In the children-of-twins (CoT) design, it is possible to explore the effects of parents on children, and vice versa, while accounting for the potential confounding effects of parent and child genes (and thus passive gene-environment correlation) and shared family environments.

The CoT design involves studying samples of twins and their children (D'Onofrio et al., 2003; Fischer, 2018; Heath et al., 1985; McAdams et al., 2014, 2018; Nance \& Corey, 1976; Silberg et al., 2010). Children inherit $50 \%$ of their DNA from each of their parents. As depicted in Figure 1, because MZ twins share all of their segregating genes, when both twins in an MZ twin-pair have children, their offspring are just as genetically related to their own parent (genetic correlation $=.50$ ) as they are to their parent's genetically identical twin (avuncular genetic correlation $=.50$ ). In contrast, because DZ twins share $50 \%$ of their segregating genes on average, when both twins in a DZ twin-pair have children, their offspring are more genetically related to their own parent (genetic correlation $=.50$ ) than they are to their parent's non-identical twin (avuncular genetic correlation $=.25$ ). Subsequently, cousins who are offspring of MZ twins are more genetically related to each other (genetic correlation $=.25$ ) compared to the offspring of DZ twins (genetic correlation $=.125$ ). Comparisons between avuncular correlations in these extended families linked by $\mathrm{MZ}$ versus $\mathrm{DZ}$ twin parents thus provide researchers with a natural, quasi-experiment for the study of associations between parent and child phenotypes.

Here, we describe the procedural and measurement aspects of the first British CoT sample, the Children of the Twins Early Development Study (CoTEDS). CoTEDS is a spin-off from the Twins Early Development Study (TEDS; Rimfeld et al., 2019). The TEDS sample includes approximately 10,000 contactable twin-pairs who have been followed longitudinally from infancy through adulthood. At the time of writing, TEDS twins were aged 22-25 years old. The zygosity of TEDS twins was assigned using a parent-reported questionnaire of physical similarity, which is found to be over 95\% accurate (Price et al., 2000), and DNA testing was undertaken where zygosity remained unclear (the current sample includes $64 \% \mathrm{DZ}, 33 \% \mathrm{MZ}$ and 3\% unknown). As TEDS twins begin to have children of their own, they are invited to join CoTEDS with their offspring. In the initial stages, CoTEDS has been designed to partially mirror the early years of TEDS data collection, to create a two-generation dataset that includes many of the same phenotypic measures on parents and offspring at corresponding stages of early development. New phenotypes are also being assessed in CoTEDS, relating specifically to parent and offspring mental health, as well as parenting behaviors and feelings.

\section{Research Aims}

CoTEDS has been designed to address several types of research questions. Our primary aim is to use the two-generation, longitudinal dataset to understand genetic and environmental factors that underpin intergenerational transmission of common traits within families, with a specific focus on the transmission of cognitive and mental health-related phenotypes. Our secondary aim is to understand the degree to which parenting affects child development and vice versa. Third, in TEDS adults, we aim to examine the genetic and environmental factors that influence individuals' experiences and behaviors during parenthood.

From the outset, CoTEDS has been designed with the goal of being able to replicate our analyses across other samples and triangulate our findings with those arising through use of alternative genetically sensitive research designs. For this reason, we have built in overlap between CoTEDS and TEDS as well as other genetically informative cohort studies to ensure that we assess many of the same phenotypes at corresponding stages of development. To date, these cohorts primarily include the prospective adoption study, the Early Growth and Development Study (EGDS; Leve et al., 2013), and two transgenerational prospective observational studies, the Norwegian Mother and Child Birth Cohort Study (MoBa; Magnus et al., 2016) and the Avon Longitudinal Study of Parents and Children (ALSPAC; Boyd et al., 2013). Ongoing data collection from EGDS, MoBa and ALSPAC encapsulates longitudinal phenotypic and genomic information on parents and offspring from prenatal stages through childhood. As CoTEDS progresses, we will explore opportunities for further overlap with additional databases. By ensuring that we employ a combination of research methodologies in our work, we will be more likely to reach valid and robust research conclusions (Rutter et al., 2001).

\section{Recruitment}

Parents are recruited to CoTEDS from the sample of approximately 20,000 contactable adult twins who remain enrolled in the TEDS. The initial TEDS recruitment strategy, retention information and sample characteristics have been described in detail elsewhere (Haworth et al., 2013; Oliver \& Plomin, 2007; Rimfeld et al., 2019; Trouton et al., 2002). Recruitment to CoTEDS commenced in March 2016 (data collection was launched the following year), with all TEDS twins invited to register their existing offspring online. CoTEDS registration for existing offspring and/or pregnancies is advertised to all TEDS families (both twins and their parents) during TEDS data collection, on the TEDS website, in the 
Table 1. Child ages at CoTEDS registration and the total registered sample in May $2019^{a}$

\begin{tabular}{lcc}
\hline $\begin{array}{l}\text { Child age } \\
\text { (years) }\end{array}$ & $\begin{array}{c}\text { Number of children } \\
\text { registered at this age }\end{array}$ & $\begin{array}{c}\text { Number of } \\
\text { children } \\
\text { at time of } \\
\text { writing } \\
\text { at this age }\end{array}$ \\
\hline $0-1$ & 260 & 82 \\
\hline $1-2$ & 99 & 126 \\
\hline $2-3$ & 76 & 113 \\
\hline $3-4$ & 46 & 89 \\
\hline $4-5$ & 28 & 50 \\
\hline $5-6$ & 25 & 42 \\
\hline $6-7$ & 11 & 25 \\
\hline $7-8$ & 6 & 19 \\
\hline $8-9$ & 2 & 6 \\
\hline $9-10$ & 0 & 1 \\
\hline $10-11$ & 1 & 1 \\
\hline Total & 554 & 554 \\
\hline
\end{tabular}

${ }^{a}$ Children registered between March 2016 and May 2019. New children registered on a continual basis.

annual TEDS newsletter, on social media, annual email circulars and by word of mouth when researchers have contact with TEDS families. Recruitment efforts are continually maintained.

CoTEDS registration includes a short screening procedure to confirm that the inclusion criteria are met for data collection: (1) the child must be a biological offspring of the TEDS twin and (2) the child must have regular contact with the TEDS twin (for twins not living with their offspring, we require that they have at least 1-3 h contact time per week; contact time is recorded for use as a covariate in analyses). We aim for twins to register their offspring at birth; however, there is no maximum child age for registration. Furthermore, we aim to register as many biological children per TEDS twin as possible, including twins in the offspring generation (as of May 2019, 2.4\% of all registered births in CoTEDS are multiples [13 twin-pairs], as compared to national statistics showing that $1.6 \%$ of all British births in 2017 were twins; Ghosh, 2019). Child ages at registration are detailed in Table 1 for all registrations between March 2016 and May 2019. These children are registered to 435 twins (79.8\% female), which includes 45 twin-pairs (where both twins in a pair have at least one registered child; $51 \% \mathrm{MZ}$ ) and 345 individual twins (of which $46 \%$ are from an MZ pair).

At each wave of data collection, twins provide informed consent and are given the option to share contact details for their child's co-parent (this may be the child's other biological parent and/or the twin's partner). Co-parents are recruited to take part in CoTEDS for the equivalent single wave of data collection. Co-parents are not recontacted for CoTEDS unless the twin nominates them again at a subsequent wave of data collection. The nature of the relationship between CoTEDS children and the co-parent providing data at each wave is carefully tracked.

\section{Data Collection Protocol}

Data collection is continually maintained alongside recruitment. The first wave of data collection (Wave 1) was launched in May 2017, involving a parent-reported questionnaire for the parents of 1-year-old CoTEDS children. The target child age for questionnaire completion is 12 months, but data are collected for all children between 12 and 23 months, with child age included as a covariate for analyses. The questionnaire is sent to participants to complete in their own time, taking approximately $60 \mathrm{~min}$ to complete online or on paper. Baseline information is collected for general demographic data and the composition and living situation of the immediate family. A battery of measures, described below, is then completed to assess several child, parenting, parent and socioecological phenotypes. Items relate to the perinatal period, first 12 months of the child's life and the weeks prior to questionnaire completion. Quality control items are used to monitor participant attention and validity of responses in sections that use large matrices of items measured along the same Likert scale. These quality control items require participants to select a specific response to the Likert scale. During data analysis, researchers will have the option to exclude participant responses on any given measure if quality control items are answered incorrectly. Prior to the launch of Wave 1, the full questionnaire battery was piloted in a sample of 195 community volunteers with infant children, who also provided quantitative and qualitative feedback on the questionnaire. Psychometric properties and participant feedback were assessed for all scales, and questionnaire edits made where appropriate.

Data collection commenced for the second wave of data collection (Wave 2) in October 2018, for the parents of 2-year-old children (target age 24 months). An adapted, age-appropriate version of the Wave 1 questionnaire is used at Wave 2, with the addition of three parent-assessed tests of child cognitive ability that are completed by parents after the questionnaire (see Table 2; Saudino et al., 1998). The Wave 2 battery was piloted in a sample of 210 community volunteers with infant children, who again provided quantitative and qualitative feedback. As with Wave 1, the Wave 2 pilot data were used to inform the composition of the final Wave 2 questionnaire. At the time of writing, we are developing the third wave of data collection (Wave 3) for the parents of 3-year-old children. As depicted in Figure 2, all parents complete data collection waves as applicable to their child's age at CoTEDS registration. Children who are registered before their first birthday follow the standard protocol, with parents invited to complete Waves 1-3 on, or shortly after, the child's corresponding birthday (see Figure 2, black arrows). Any parents registering a child older than 23 months will be invited to retrospectively complete a subset of baseline questions from Wave 1, after they have completed any other applicable waves of data collection (see Figure 2, grey arrows).

\section{Measures, Waves 1 and 2}

Within the space constraints of the Wave 1 and 2 questionnaires, we included key phenotypes that have previously been theoretically or empirically related to the development of cognitive and mental health-related traits in children. Where possible, we have used well-established, documented and validated measures. Where no sample-appropriate, questionnaire-based measure with adequate psychometric properties could be found, we designed our own. A summary of the measures, including number of items and overlap between CoTEDS Waves 1 and 2, is outlined in Table 2. For some phenotypes, the number of items differs between waves if edits were made to ensure that measures were age-appropriate and/or to accommodate space constraints in each questionnaire. Table 2 also details intentional measurement overlap with other genetically informative cohort studies. 
Table 2. Summary of measures included in CoTEDS Waves 1 and 2

\begin{tabular}{|c|c|c|c|c|c|c|}
\hline \multirow[b]{2}{*}{ Phenotype } & \multirow[b]{2}{*}{ Measure } & \multicolumn{2}{|c|}{$\begin{array}{l}\text { Number of } \\
\text { items }\end{array}$} & \multirow[b]{2}{*}{ Subscale(s) } & \multirow{2}{*}{$\begin{array}{l}\text { Measure } \\
\text { included in } \\
\text { TEDS, EGDS, } \\
\text { ALSPAC or } \\
\mathrm{MOBa}^{\mathrm{a}}\end{array}$} & \multirow[b]{2}{*}{ Reference } \\
\hline & & $\begin{array}{c}\text { Wave } \\
1\end{array}$ & $\begin{array}{l}\text { Wave } \\
2\end{array}$ & & & \\
\hline \multicolumn{7}{|l|}{ Child } \\
\hline \multirow[t]{3}{*}{ Medical } & Pregnancy & 26 & - & $\begin{array}{l}\text { Duration, supplements, substance use, } \\
\text { medical }\end{array}$ & TEDS & $\begin{array}{l}\text { Created for TEDS and } \\
\text { CoTEDS }\end{array}$ \\
\hline & Birth & 5 & - & Duration, medical & TEDS & $\begin{array}{l}\text { Created for TEDS and } \\
\text { CoTEDS }\end{array}$ \\
\hline & Health & 11 & 7 & $\begin{array}{l}\text { Health at birth, hospital stays, specific } \\
\text { health or development problems, antibiotic } \\
\text { use }\end{array}$ & TEDS & $\begin{array}{l}\text { Created for TEDS and } \\
\text { COTEDS }\end{array}$ \\
\hline \multirow[t]{4}{*}{ Temperament } & $\begin{array}{l}\text { Infant Toddler Social and } \\
\text { Emotional Assessment (ITSEA) }\end{array}$ & 12 & 12 & Aggression/defiance & MoBa & Carter et al. (2003) \\
\hline & $\begin{array}{l}\text { Infant Characteristics } \\
\text { Questionnaire (ICQ) }\end{array}$ & 11 & 11 & Fussy/difficult & EGDS, MoBa & Bates et al. (1979) \\
\hline & $\begin{array}{l}\text { The Emotionality, Activity and } \\
\text { Shyness Temperament Survey } \\
\text { (EAS) }\end{array}$ & 25 & 25 & $\begin{array}{l}\text { Emotionality, activity, shyness, sociability, } \\
\text { attention span-persistence }\end{array}$ & ALSPAC, MoBa & $\begin{array}{l}\text { Mathiesen and Tambs } \\
\text { (1999), Rowe and } \\
\text { Plomin (1977) }\end{array}$ \\
\hline & Perceived crying problem & 1 & 1 & - & - & Created for CoTEDS \\
\hline \multirow[t]{2}{*}{ Sleep } & $\begin{array}{l}\text { Brief Infant Sleep } \\
\text { Questionnaire (BISQ) }\end{array}$ & 11 & 11 & - & - & $\begin{array}{l}\text { Sadeh (2004), Sadeh } \\
\text { et al. (2009) }\end{array}$ \\
\hline & Perceived sleep problem & 1 & 1 & - & - & Created for CoTEDS \\
\hline $\begin{array}{l}\text { Soothing } \\
\text { techniques }\end{array}$ & $\begin{array}{l}\text { Use of comfort object/thumb } \\
\text { sucking }\end{array}$ & 3 & 3 & - & - & Created for CoTEDS \\
\hline $\begin{array}{l}\text { Feeding } \\
\text { (breastmilk) }\end{array}$ & $\begin{array}{l}\text { Duration, exclusivity and } \\
\text { difficulty }\end{array}$ & 8 & 3 & - & TEDS & $\begin{array}{l}\text { Created for TEDS and } \\
\text { CoTEDS }\end{array}$ \\
\hline \multirow[t]{2}{*}{ Feeding (solids) } & Age started & - & 1 & - & - & Created for CoTEDS \\
\hline & Perceived feeding problem & 1 & 2 & - & - & Created for CoTEDS \\
\hline $\begin{array}{l}\text { Developmental } \\
\text { milestones }\end{array}$ & $\begin{array}{l}\text { The Denver Developmental } \\
\text { Screening Test }\end{array}$ & 21 & - & $\begin{array}{l}\text { Personal-social, fine motor, gross motor, } \\
\text { language }\end{array}$ & ALSPAC & $\begin{array}{l}\text { Frankenburg and Dodds } \\
(1967)\end{array}$ \\
\hline \multirow[t]{2}{*}{$\begin{array}{l}\text { Cognitive } \\
\text { development }\end{array}$} & $\begin{array}{l}\text { Parent Report of Children's } \\
\text { Abilities (PARCA): parent } \\
\text { report }\end{array}$ & - & 26 & - & TEDS & $\begin{array}{l}\text { Created for TEDS; } \\
\text { Saudino et al. (1998) }\end{array}$ \\
\hline & $\begin{array}{l}\text { Parent Report of Children's } \\
\text { Abilities (PARCA): parent- } \\
\text { assessed child tasks }{ }^{\text {b }}\end{array}$ & - & $\begin{array}{c}1,7 \\
8\end{array}$ & $\begin{array}{l}\text { Paper folding, copying actions, matching } \\
\text { shapes }\end{array}$ & TEDS & $\begin{array}{l}\text { Created for TEDS; } \\
\text { Saudino et al. (1998) }\end{array}$ \\
\hline \multirow{3}{*}{$\begin{array}{l}\text { Language } \\
\text { development }\end{array}$} & Languages and bilingualism & 1 & 3 & - & - & Created for CoTEDS \\
\hline & $\begin{array}{l}\text { Vocabulary, adapted from the } \\
\text { MacArthur Communicative } \\
\text { Development Inventory (MCDI) }\end{array}$ & - & 30 & - & TEDS & $\begin{array}{l}\text { Created for TEDS, } \\
\text { adapted for CoTEDS; } \\
\text { Dale et al. (1998), } \\
\text { Fenson et al. (1994) }\end{array}$ \\
\hline & $\begin{array}{l}\text { Sentence Complexity, adapted } \\
\text { from the MacArthur } \\
\text { Communicative Development } \\
\text { Inventory (MCDI) }\end{array}$ & - & 13 & - & TEDS & $\begin{array}{l}\text { Created for TEDS; } \\
\text { Dale et al. (2000), } \\
\text { Fenson } \\
\text { et al. (1994) }\end{array}$ \\
\hline \multirow[t]{2}{*}{ Psychopathology } & $\begin{array}{l}\text { Strengths and Difficulties } \\
\text { Questionnaire (SDQ) for 2-4- } \\
\text { year-olds }\end{array}$ & - & 25 & $\begin{array}{l}\text { Prosocial, hyperactivity, conduct problems, } \\
\text { emotional problems, peer problems, total } \\
\text { difficulties }\end{array}$ & TEDS, ALSPAC & Goodman (2001) \\
\hline & $\begin{array}{l}\text { Infant Toddler Social and } \\
\text { Emotional Assessment (ITSEA) }\end{array}$ & - & 13 & Maladaptive behavior & MoBa & Carter et al. (2003) \\
\hline Twin zygosity & $\begin{array}{l}\text { Zygosity questionnaire for } \\
\text { young twins }\end{array}$ & 17 & - & - & TEDS & $\begin{array}{l}\text { Goldsmith (1991), } \\
\text { Price et al. (2000) }\end{array}$ \\
\hline
\end{tabular}


Table 2. (Continued)

\begin{tabular}{|c|c|c|c|c|c|c|}
\hline \multirow[b]{2}{*}{ Phenotype } & \multirow[b]{2}{*}{ Measure } & \multicolumn{2}{|c|}{$\begin{array}{l}\text { Number of } \\
\text { items }\end{array}$} & \multirow[b]{2}{*}{ Subscale(s) } & \multirow{2}{*}{$\begin{array}{c}\text { Measure } \\
\text { included in } \\
\text { TEDS, EGDS, } \\
\text { ALSPAC or } \\
\mathrm{MOBa}^{\mathrm{a}}\end{array}$} & \multirow[b]{2}{*}{ Reference } \\
\hline & & $\begin{array}{c}\text { Wave } \\
1\end{array}$ & $\begin{array}{c}\text { Wave } \\
2\end{array}$ & & & \\
\hline \multicolumn{7}{|l|}{ Parenting } \\
\hline \multirow[t]{4}{*}{ Behavior } & $\begin{array}{l}\text { Parental Cognitions and } \\
\text { Conduct Toward the Infant } \\
\text { Scale (PACOTIS) }\end{array}$ & 11 & 11 & $\begin{array}{l}\text { Parental hostile-reactive behaviors, parental } \\
\text { overprotection }\end{array}$ & - & Boivin et al. (2005) \\
\hline & The Parenting Scale & - & 11 & Verbosity, over-reactivity, laxness & EGDS & Arnold et al. (1993) \\
\hline & $\begin{array}{l}\text { Parental language input } \\
\text { behavior }\end{array}$ & - & 10 & - & - & Created for CoTEDS \\
\hline & Response to child at night & 1 & 2 & - & - & Created for CoTEDS \\
\hline \multirow{2}{*}{ Feelings } & $\begin{array}{l}\text { Parental Feelings } \\
\text { Questionnaire (PFQ) }\end{array}$ & 7 & 7 & $\begin{array}{l}\text { Negative feelings toward the child, positive } \\
\text { feelings toward the child }\end{array}$ & TEDS & Deater-Deckard (2000) \\
\hline & Parenting Daily Hassles (PDH) & 12 & 5 & $\begin{array}{l}\text { Frequency of hassles, intensity of hassles, } \\
\text { parenting task hassles, challenging behavior } \\
\text { hassles }\end{array}$ & EGDS & $\begin{array}{l}\text { Crnic and Greenberg } \\
\text { (1990) }\end{array}$ \\
\hline $\begin{array}{l}\text { Beliefs and } \\
\text { principles }\end{array}$ & $\begin{array}{l}\text { Baby Care Questionnaire } \\
\text { (BBQ) }\end{array}$ & 20 & - & Structure, attunement & - & $\begin{array}{l}\text { Winstanley and Gattis } \\
\text { (2013) }\end{array}$ \\
\hline \multirow[t]{2}{*}{ Play } & $\begin{array}{l}\text { Parent Play Questionnaire } \\
\text { (PPQ) }\end{array}$ & 13,17 & 16,11 & $\begin{array}{l}\text { Frequency of parent-child play, parent } \\
\text { attitudes toward parent-child play }\end{array}$ & - & Created for CoTEDS \\
\hline & $\begin{array}{l}\text { Parent and child comfort with } \\
\text { risky play }\end{array}$ & - & 18 & $\begin{array}{l}\text { Rough and tumble, lost/disappear/ } \\
\text { unsupervised, speed, height, dangerous } \\
\text { elements, tools }\end{array}$ & - & Created for CoTEDS \\
\hline Childcare & $\begin{array}{l}\text { Maternity/paternity leave and } \\
\text { childcare provision }\end{array}$ & 7 & 2 & - & TEDS & $\begin{array}{l}\text { Created for TEDS and } \\
\text { COTEDS }\end{array}$ \\
\hline \multicolumn{7}{|l|}{ Parent } \\
\hline \multirow[t]{3}{*}{ Depression } & $\begin{array}{l}\text { Edinburgh Postnatal } \\
\text { Depression Scale (EPDS) }\end{array}$ & 10 & - & - & $\begin{array}{l}\text { TEDS, EGDS, } \\
\text { ALSPAC, MoBa }\end{array}$ & Cox et al. (1987) \\
\hline & $\begin{array}{l}\text { Major depression during } \\
\text { child's pregnancy and first } \\
\text { year after birth }\end{array}$ & 6 & - & - & MoBa & Kendler et al. (1993) \\
\hline & $\begin{array}{l}\text { Short Mood and Feelings } \\
\text { Questionnaire (SMFQ) }\end{array}$ & - & 13 & - & $\begin{array}{l}\text { TEDS (in } \\
\text { offspring), } \\
\text { ALSPAC (in } \\
\text { offspring) }\end{array}$ & Angold et al. (1995) \\
\hline \multirow[t]{2}{*}{ Anxiety } & $\begin{array}{l}\text { Generalized Anxiety } \\
\text { Disorder-7 (GAD-7) }\end{array}$ & - & 7 & - & - & Spitzer et al. (2006) \\
\hline & $\begin{array}{l}\text { Adult version of the Revised } \\
\text { Child Anxiety and Depression } \\
\text { Scale (RCADS) }\end{array}$ & - & 20 & $\begin{array}{l}\text { Separation anxiety, generalized anxiety, } \\
\text { obsessive-compulsive, social anxiety, panic }\end{array}$ & EGDS & $\begin{array}{l}\text { Adapted for CoTEDS; } \\
\text { Chorpita et al. (2000), } \\
\text { Gregory et al. (2011) }\end{array}$ \\
\hline Irritability & $\begin{array}{l}\text { The Affective Reactivity Index } \\
\text { (ARI) }\end{array}$ & - & 7 & - & - & Stringaris et al. (2012) \\
\hline
\end{tabular}


Table 2. (Continued)

\begin{tabular}{|c|c|c|c|c|c|c|}
\hline \multirow[b]{2}{*}{ Phenotype } & \multirow[b]{2}{*}{ Measure } & \multicolumn{2}{|c|}{$\begin{array}{l}\text { Number of } \\
\text { items }\end{array}$} & \multirow[b]{2}{*}{ Subscale(s) } & \multirow{2}{*}{$\begin{array}{l}\text { Measure } \\
\text { included in } \\
\text { TEDS, EGDS, } \\
\text { ALSPAC or } \\
\text { MoBa }^{\text {a }}\end{array}$} & \multirow[b]{2}{*}{ Reference } \\
\hline & & $\begin{array}{c}\text { Wave } \\
1\end{array}$ & $\begin{array}{l}\text { Wave } \\
2\end{array}$ & & & \\
\hline \multirow[t]{3}{*}{ Substance use } & $\begin{array}{l}\text { Alcohol Use Disorders } \\
\text { Identification Test (AUDIT) }\end{array}$ & - & 10 & $\begin{array}{l}\text { Alcohol consumption, drinking } \\
\text { behaviors, alcohol-related problems }\end{array}$ & $\begin{array}{l}\text { TEDS (in } \\
\text { offspring), } \\
\text { ALSPAC (in } \\
\text { offspring), } \\
\text { MoBa }\end{array}$ & Saunders et al. (1993) \\
\hline & Smoking & - & 8 & Cigarettes, electronic cigarettes & - & Created for CoTEDS \\
\hline & Recreational drug use & - & 5 & $\begin{array}{l}\text { Cannabis, sedatives, stimulants, } \\
\text { hallucinogens, opioids }\end{array}$ & - & Created for CoTEDS \\
\hline \multirow[t]{3}{*}{ Sleep } & $\begin{array}{l}\text { The Pittsburgh Sleep Quality } \\
\text { Index (PSQI) }\end{array}$ & 18 & 18 & $\begin{array}{l}\text { Subjective sleep quality, sleep latency, sleep } \\
\text { duration, habitual sleep efficiency, sleep } \\
\text { disturbances, use of sleep medication, } \\
\text { daytime drowsiness }\end{array}$ & TEDS, EGDS & Buysse et al. (1989) \\
\hline & Sleep disruption due to child & 9 & 9 & - & - & Created for CoTEDS \\
\hline & Night shifts & 1 & 1 & - & - & Created for CoTEDS \\
\hline $\begin{array}{l}\text { Therapy service } \\
\text { use }\end{array}$ & $\begin{array}{l}\text { Receipt of psychological } \\
\text { treatment/therapy }\end{array}$ & 2 & 2 & - & EGDS & Created for EGDS \\
\hline $\begin{array}{l}\text { Psychiatric } \\
\text { diagnoses }\end{array}$ & $\begin{array}{l}\text { Lifetime diagnosis of a } \\
\text { psychiatric disorder }\end{array}$ & 1 & - & - & - & Davis et al. (2018) \\
\hline \multirow[t]{2}{*}{$\begin{array}{l}\text { Romantic } \\
\text { relationship }\end{array}$} & $\begin{array}{l}\text { Behavior Affect Rating Scale } \\
\text { (BARS) }\end{array}$ & 22 & 22 & Warmth, hostility & EGDS & $\begin{array}{l}\text { Cui et al. (2005), Melby } \\
\text { et al. (1995) }\end{array}$ \\
\hline & Relationship quality & 6 & - & Happiness, satisfaction, commitment & EGDS & Conger et al. (2011) \\
\hline \multicolumn{7}{|l|}{ Socioecological } \\
\hline \multirow{2}{*}{$\begin{array}{l}\text { Home } \\
\text { environment }\end{array}$} & Living situation & 4 & - & Type of home, household density & - & Created for CoTEDS \\
\hline & $\begin{array}{l}\text { Confusion, Hubbub, and } \\
\text { Order Scale (CHAOS) }\end{array}$ & 11 & - & Calm, chaos & TEDS & Matheny et al. (1995) \\
\hline \multirow[t]{4}{*}{$\begin{array}{l}\text { Quality of life } \\
\text { and social } \\
\text { support }\end{array}$} & $\begin{array}{l}\text { World Health Organization's } \\
\text { Quality of Life Instrument- } \\
\text { short version (WHOQOL-BREF) }\end{array}$ & - & 11 & Environment, social relationships & MoBa & Skevington et al. (2004) \\
\hline & Involvement of other adults & 3 & 3 & $\begin{array}{l}\text { Parenting support, financial support, other } \\
\text { adults living in the home }\end{array}$ & - & Created for CoTEDS \\
\hline & Family financial questionnaire & 6 & - & Material needs, making ends meet & EGDS & Conger et al. (1992) \\
\hline & Financial strain & 1 & - & - & - & Created for CoTEDS \\
\hline \multirow[t]{3}{*}{$\begin{array}{l}\text { Socioeconomic } \\
\text { status }\end{array}$} & Income sources and amount & 6 & - & - & TEDS & $\begin{array}{l}\text { Created for TEDS and } \\
\text { CoTEDS }\end{array}$ \\
\hline & $\begin{array}{l}\text { Parent highest educational } \\
\text { qualification }\end{array}$ & 1 & - & - & TEDS & $\begin{array}{l}\text { Created for TEDS and } \\
\text { CoTEDS }\end{array}$ \\
\hline & Parent occupation & 3 & 1 & $\begin{array}{l}\text { Employment status, occupation } \\
\text { classification }\end{array}$ & TEDS & Elias and Birch (2010) \\
\hline
\end{tabular}

${ }^{a}$ TEDS, Twins Early Development Study; EGDS, Early Growth and Development Study; ALSPAC, Avon Longitudinal Study of Parents and Children; MoBa, Norwegian Mother and Child Birth Cohort Study.

bParent-assessed tasks of child cognitive ability — completed by parents with the child, after the questionnaire battery.

\section{Future Directions}

\section{Data Collection}

Following the development and launch of Wave 3, we plan to continue with further waves of data collection to be completed as the children of TEDS twins grow older, including questionnaire-based measurements of new age-appropriate phenotypes post infancy (e.g. comprehensive measures of child psychopathology and cognitive development, as well as parenting measures relating to early and middle childhood). Alongside questionnaire-based measures, we plan to collect other forms of data, for example, using observational methods to examine parent-child interactions (e.g. Ginsburg et al., 2006; Oliver \& Pike, 2019). We will focus on developing our study design to enable longitudinal data collection from a range of sources within our ever-growing sample. New possibilities include harnessing in-home technologies to reach families, for example, using video calls or gamified mobile applications to remotely examine traits and parent-child relationships. Future directions include plans to collect genotype data from the children and partners of TEDS twins, to maximize learning 


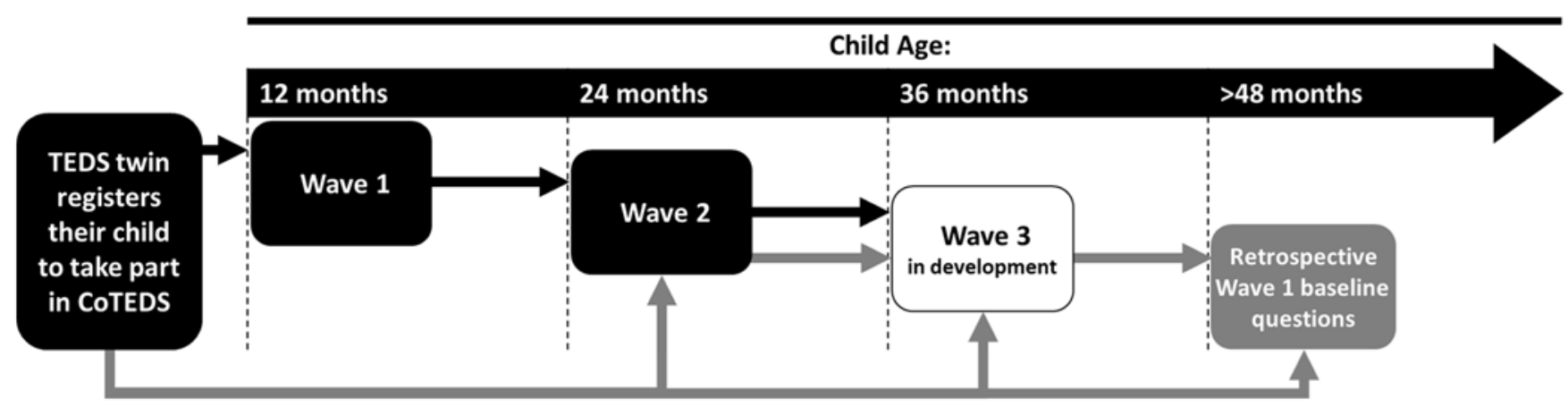

Fig. 2. Data collection protocol in May 2019. ${ }^{a}$

Note: ${ }^{a}$ Black arrows: COTEDS children registered before their first birthday follow the standard protocol from 12 months. Grey arrows: CoTEDS children registered after their second birthday complete any waves applicable to their age, followed by retrospective Wave 1 baseline questions.

from our two-generation pedigree analyses with state-of-the-art methods in statistical genetics.

\section{Data Analyses}

Opportunities to examine genetic and environmental intergenerational effects will be rich in CoTEDS, using longitudinal data relating to the phenotypes described in Table 2, alongside data from the main TEDS study. The number of twin-pairs with children required to reach $80 \%$ power to detect intergenerational genetic transmission of varying magnitudes has been estimated elsewhere by McAdams et al. (2018). Crucially, the authors show that the required number of twin-pairs is reduced if data on two or more children are included per twin (i.e. using the multiplechildren-of-twins [MCoT] design). Furthermore, by examining twin phenotypes measured in TEDS and offspring phenotypes measured in CoTEDS, we can also include twin-pairs where only one twin in the pair has children in CoTEDS. Including these 'incomplete' extended families will allow us to maximize the number of avuncular associations in extended MCoT models. We therefore expect that our first genetically informed intergenerational analyses in CoTEDS will use data from all combinations of twin-pairs with children (i.e. one child per twin, two children per twin and incomplete extended families). Recruiting nonbiological offspring of TEDS twins to CoTEDS (e.g. children conceived via egg or sperm donors or adopted children) will be another possible avenue to increase power for extended MCoT analyses in the future. Further analyses will have the potential to span three generations across time, by combining longitudinal data on TEDS twins, their parents and their offspring. Hence, we will also be able to ask questions relating to societal and cultural changes across generations. Triangulating this work with analyses in other datasets will enable us to make a robust contribution to the literature regarding associations between parents and children during early child development.

\section{Summary}

CoTEDS will include genetically sensitive, prospective information on both parents and their offspring from infancy. As the number of children born to TEDS twins continues to increase over the coming years, CoTEDS is in place to develop an invaluable resource for the examination of genetic and environmental factors that shape child development, helping us to better understand the role that parents play in this process.
Acknowledgments. We thank the families involved in the Twins Early Development Study (TEDS) and Children of TEDS (CoTEDS) for their ongoing participation and support for our research. We thank the research teams who have managed and coordinated TEDS and CoTEDS data collection. With special thanks to Rachel Ogden, Meredith Han, Laura Okonajiofor and Rebecca Watkins-Muleba.

Financial support. CoTEDS data collection and the positions of T.M. and Y.A. are funded by a Sir Henry Dale Fellowship awarded to T.M., jointly funded by the Wellcome Trust and the Royal Society $(107706 / Z / 15 / Z)$. T.E. is part funded by a program grant from the UK Medical Research Council (MR/M021475/1), the National Institute for Health Research (NIHR) Biomedical Research Centre at South London and Maudsley NHS Foundation Trust and King's College London. TEDS, and the position of A.M., is supported by a program grant to R.P. from the UK Medical Research Council (MR/M021475/1 and previously G0901245), with additional support from the US National Institutes of Health (HD044454; HD059215). R.P. is supported by a Medical Research Council Research Professorship award (G19/2) and an European Research Council Advanced Investigator award (295366). The funders had no role in study design, data collection and analysis, decision to publish or preparation of the manuscript. The views expressed are those of the authors.

\section{Conflict of interest. None.}

Ethical standards. The authors assert that all procedures contributing to this work comply with the ethical standards of the relevant national and institutional committees on human experimentation and with the Helsinki Declaration of 1975, as revised in 2008. Ethical approval was granted by the Psychiatry, Nursing and Midwifery Research Ethics Subcommittee, King's College London.

\section{References}

Ahmadzadeh, Y. I., Eley, T. C., Leve, L. D., Shaw, D. S., Natsuaki, M. N., Reiss, D., ... McAdams, T. A. (2019). Anxiety in the family: A genetically informed analysis of transactional associations between mother, father and child anxiety symptoms. Journal of Child Psychology and Psychiatry. Advance online publication. doi:10.1111/jcpp.13068

Angold, A., Costello, E. J., Messer, S. C., \& Pickles, A. (1995). Development of a short questionnaire for use in epidemiological studies of depression in children and adolescents [Press release].

Arnold, D. S., O'Leary, S. G., Wolff, L. S., \& Acker, M. M. (1993). The Parenting Scale: A measure of dysfunctional parenting in discipline situations. Psychological Assessment, 5, 137-144.

Avinun, R., \& Knafo, A. (2014). Parenting as a reaction evoked by children's genotype: A meta-analysis of children-as-twins studies. Personality and Social Psychology Review, 18, 87-102.

Bates, J. E., Freeland, C. A., \& Lounsbury, M. L. (1979). Measurement of infant difficultness. Child Development, 50, 794-803.

Boivin, M., Perusse, D., Dionne, G., Saysset, V., Zoccolillo, M., Tarabulsy, G. M., ... Tremblay, R. E. (2005). The genetic-environmental etiology of parents' perceptions and self-assessed behaviours toward their 
5-month-old infants in a large twin and singleton sample. Journal of Child Psychology and Psychiatry, 46, 612-630.

Bouchard, T. J., \& McGue, M. (1981). Familial studies of intelligence - A review. Science, 212, 1055-1059.

Boutwell, B. B., \& Beaver, K. M. (2010). The intergenerational transmission of low self-control. Journal of Research in Crime and Delinquency, 47, 174-209.

Boyd, A., Golding, J., Macleod, J., Lawlor, D. A., Fraser, A., Henderson, J., Smith, G. D. (2013). Cohort Profile: The 'Children of the 90s' - The index offspring of the Avon Longitudinal Study of Parents and Children. International Journal of Epidemiology, 42, 111-127.

Buysse, D. J., Reynolds, C. F., Monk, T. H., Berman, S. R., \& Kupfer, D. J. (1989). The Pittsburgh sleep quality index: A new instrument for psychiatric practice and research. Psychiatry Research, 28, 193-213.

Carter, A. S., Briggs-Gowan, M. J., Jones, S. M., \& Little, T. D. (2003). The Infant-Toddler Social and Emotional Assessment (ITSEA): Factor structure, reliability, and validity. Journal of Abnormal Child Psychology, 31, 495-514.

Chassin, L., Presson, C., Seo, D. C., Sherman, S. J., Macy, J., Wirth, R. J., \& Curran, P. (2008). Multiple trajectories of cigarette smoking and the intergenerational transmission of smoking: A multigenerational, longitudinal study of a midwestern community sample. Health Psychology, 27, 819-828.

Chorpita, B. F., Yim, L., Moffitt, C., Umemoto, L. A., \& Francis, S. E. (2000). Assessment of symptoms of DSM-IV anxiety and depression in children: A revised child anxiety and depression scale. Behaviour Research and Therapy, $38,835-855$.

Conger, R. D., Conger, K. J., Elder, G. H., Lorenz, F. O., Simons, R. L., \& Whitbeck, L. B. (1992). A family process model of economic hardship and adjustment of early adolescent boys. Child Development, 63, 526-541.

Conger, R. D., Lasley, P., Lorenz, F. O., Simons, R., Whitbeck, L. B., Elder, G. H. Jr., \& Norem, R. (2011). Iowa youth and families project, 1989-1992. Ann Arbor, MI: Inter-university Consortium for Political and Social Research, 2011-11-03. doi: 10.3886/ICPSR26721.v2

Cox, J. L., Holden, J. M., \& Sagovsky, R. (1987). Detection of postnatal depression. Development of the 10-item Edinburgh Postnatal Depression Scale. British Journal of Psychiatry, 150, 782-786.

Crnic, K. A., \& Greenberg, M. T. (1990). Minor parenting stresses with young children. Child Development, 61, 1628-1637.

Cui, M., Lorenz, F. O., Conger, R. D., Melby, J. N., \& Bryant, C. M. (2005). Observer, self-, and partner reports of hostile behaviors in romantic relationships. Journal of Marriage and Family, 67, 1169-1181.

Dale, P. S., Dionne, G., Eley, T. C., \& Plomin, R. (2000). Lexical and grammatical development: A behavioural genetic perspective. Journal of Child Language, 27, 619-642.

Dale, P. S., Simonoff, E., Bishop, D. V., Eley, T. C., Oliver, B., Price, T. S., ... Plomin, R. (1998). Genetic influence on language delay in two-year-old children. Nature Neuroscience, 1, 324-328.

Davis, K. A. S., Coleman, J. R. I., Adams, M., Allen, N., Breen, G., Cullen, B., . Hotopf, M. (2018). Mental health in UK Biobank: Development, implementation and results from an online questionnaire completed by 157366 participants. BJPsych Open, 4, 83-90.

Deater-Deckard, K. (2000). Parenting and child behavioral adjustment in early childhood: A quantitative genetic approach to studying family processes. Child Development, 71, 468-484.

D’Onofrio, B. M., Turkheimer, E. N., Eaves, L. J., Corey, L. A., Berg, K., Solaas, M. H., \& Emery, R. E. (2003). The role of the children of twins design in elucidating causal relations between parent characteristics and child outcomes. Journal of Child Psychology and Psychiatry, 44, 1130-1144.

Elias, P., \& Birch, M. (2010). SOC2010: The revision of the Standard Occupational Classification 2000. Coventry, UK: Institute for Employment Research, University of Warwick.

Fenson, L., Dale, P. S., Reznick, J. S., Bates, E., Thal, D. J., \& Pethick, S. J. (1994). Variability in early communicative development. Monographs of the Society for Research in Child Development, 59, 1-173; discussion 174-185.

Fischer, M. (2018). Psychoses in the offspring of schizophrenic monozygotic twins and their normal co-twins. British Journal of Psychiatry, 118, 43-52.

Frankenburg, W. K., \& Dodds, J. B. (1967). The Denver developmental screening test. The Journal of Pediatrics, 71, 181-191.
Ghosh, K. (2019). Birth characteristics in England and Wales: 2017. Retrieved from https://www.ons.gov.uk/peoplepopulationandcommunity/birthsdeath sandmarriages/livebirths/bulletins/birthcharacteristicsinenglandandwales/2017.

Ginsburg, G. S., Grover, R. L., Cord, J. J., \& Ialongo, N. (2006). Observational measures of parenting in anxious and nonanxious mothers: Does type of task matter? Journal of Clinical Child \& Adolescent Psychology, 35, 323-328.

Goldsmith, H. H. (1991). A zygosity questionnaire for young twins: A research note. Behavior Genetics, 21, 257-269.

Goodman, R. (2001). Psychometric properties of the strengths and difficulties questionnaire. Journal of the American Academy of Child and Adolescent Psychiatry, 40, 1337-1345.

Gregory, A. M., Buysse, D. J., Willis, T. A., Rijsdijk, F. V., Maughan, B., Rowe, R., ... Eley, T. C. (2011). Associations between sleep quality and anxiety and depression symptoms in a sample of young adult twins and siblings. Journal of Psychosomatic Research, 71, 250-255.

Haworth, C. M. A., Davis, O. S. P., \& Plomin, R. (2013). Twins Early Development Study (TEDS): a genetically sensitive investigation of cognitive and behavioral development from childhood to young adulthood. Twin Research and Human Genetics, 16, 117-125.

Heath, A. C., Kendler, K. S., Eaves, L. J., \& Markell, D. (1985). The resolution of cultural and biological inheritance: Informativeness of different relationships. Behavior Genetics, 15, 439-465.

Hertz, T., Jayasundera, T., Piraino, P., Selcuk, S., Smith, N., \& Verashchagina, A. (2007). The inheritance of educational inequality: International comparisons and fifty-year trends. Advances in Economic Analysis \& Policy, 7, 1775-1775.

Jaaskelainen, A., Pussinen, J., Nuutinen, O., Schwab, U., Pirkola, J., Kolehmainen, M., ... Laitinen, J. (2011). Intergenerational transmission of overweight among Finnish adolescents and their parents: A 16-year follow-up study. International Journal of Obesity, 35, 1289-1294.

Kendler, K. S., Neale, M. C., Kessler, R. C., Heath, A. C., \& Eaves, L. J. (1993). The lifetime history of major depression in women: Reliability of diagnosis and heritability. Archives of General Psychiatry, 50, 863-870.

Koukounari, A., Pickles, A., Hill, J., \& Sharp, H. (2015). Psychometric properties of the Parent-Infant Caregiving Touch Scale. Frontiers in Psychology, 6, 1887-1887.

Leve, L. D., Neiderhiser, J. M., Shaw, D. S., Ganiban, J., Natsuaki, M. N., \& Reiss, D. (2013). The early growth and development study: A prospective adoption study from birth through middle childhood. Twin Research and Human Genetics, 16, 412-423.

Magnus, P., Birke, C., Vejrup, K., Haugan, A., Alsaker, E., Daltveit, A. K., .. Stoltenberg, C. (2016). Cohort profile update: The Norwegian Mother and Child Cohort Study (MoBa). International Journal of Epidemiology, 45, 382-388.

Majdandžić, M., de Vente, W., \& Bögels, S. M. (2016). Challenging parenting behavior from infancy to toddlerhood: Etiology, measurement, and differences between fathers and mothers. Infancy, 21, 423-452.

Matheny, A. P., Wachs, T. D., Ludwig, J. L., \& Phillips, K. (1995). Bringing order out of chaos: Psychometric characteristics of the confusion, hubbub, and order scale. Journal of Applied Developmental Psychology, 16, 429-444.

Mathiesen, K. S., \& Tambs, K. (1999). The EAS temperament questionnairefactor structure, age trends, reliability, and stability in a Norwegian sample. Journal of Child Psychology and Psychiatry, 40, 431-439.

McAdams, T. A., Hannigan, L. J., Eilertsen, E. M., Gjerde, L. C., Ystrom, E., \& Rijsdijk, F. V. (2018). Revisiting the children-of-twins design: Improving existing models for the exploration of intergenerational associations. Behavior Genetics, 48, 397-412.

McAdams, T. A., Neiderhiser, J. M., Rijsdijk, F. V., Narusyte, J., Lichtenstein, P., \& Eley, T. C. (2014). Accounting for genetic and environmental confounds in associations between parent and child characteristics: A systematic review of children-of-twins studies. Psychological Bulletin, 140, 1138-1173.

McAdams, T. A., Rijsdijk, F. V., Narusyte, J., Ganiban, J. M., Reiss, D., Spotts, E., ... Eley, T. C. (2017). Associations between the parent-child relationship and adolescent self-worth: A genetically informed study of twin parents and their adolescent children. Journal of Child Psychology and Psychiatry, 58, 46-54. 
Melby, J. N., Conger, R. D., Ge, X., \& Warner, T. D. (1995). The use of structural equation modeling in assessing the quality of marital observations. Journal of Family Psychology, 9, 280-293.

Micco, J. A., Henin, A., Mick, E., Kim, S., Hopkins, C. A., Biederman, J., \& Hirshfeld-Becker, D. R. (2009). Anxiety and depressive disorders in offspring at high risk for anxiety: A meta-analysis. Journal of Anxiety Disorders, 23, 1158-1164.

Nance, W. E., \& Corey, L. A. (1976). Genetic models for the analysis of data from the families of identical twins. Genetics, 83, 811-826.

Oliver, B. R., \& Pike, A. (2019). Maternal parenting observed using a novel online observation tool predicts maternal reports of children's disruptive behaviour. Manuscript submitted for publication.

Oliver, B. R., \& Plomin, R. (2007). Twins' Early Development Study (TEDS): A multivariate, longitudinal genetic investigation of language, cognition and behavior problems from childhood through adolescence. Twin Research and Human Genetics, 10, 96-105.

Oliver, B. R., Trzaskowski, M., \& Plomin, R. (2014). Genetics of parenting: The power of the dark side. Developmental Psychology, 50, 1233-1240.

Plomin, R., DeFries, J. C., \& Loehlin, J. C. (1977). Genotype-environment interaction and correlation in the analysis of human behavior. Psychological Bulletin, 84, 309-322.

Polderman, T. J., Benyamin, B., de Leeuw, C. A., Sullivan, P. F., van Bochoven, A., Visscher, P. M., \& Posthuma, D. (2015). Meta-analysis of the heritability of human traits based on fifty years of twin studies. Nature Genetics, 47, 702-709.

Price, T. S., Freeman, B., Craig, I., Petrill, S. A., Ebersole, L., \& Plomin, R. (2000). Infant zygosity can be assigned by parental report questionnaire data. Twin Research, 3, 129-133.

Rimfeld, K., Malanchini, M., Spargo, T., Spickernell, G., Selzam, S., McMillan, A., .. Plomin, R. (2019). Twins Early Development Study: A genetically sensitive investigation into behavioural and cognitive development from infancy to emerging adulthood. PsyArXiv. doi:10. 31234/osf.io/xqh52

Rowe, D. C., \& Plomin, R. (1977). Temperament in early childhood. Journal of Personality Assessment, 41, 150-156.

Rutter, M., Pickles, A., Murray, R., \& Eaves, L. (2001). Testing hypotheses on specific environmental causal effects on behavior. Psychological Bulletin, 127, 291-324.
Sadeh, A. (2004). A brief screening questionnaire for infant sleep problems: Validation and findings for an Internet sample. Pediatrics, 113, e570-577.

Sadeh, A., Mindell, J. A., Luedtke, K., \& Wiegand, B. (2009). Sleep and sleep ecology in the first 3 years: A web-based study. Journal of Sleep Research, 18, 60-73.

Saudino, K. J., Dale, P. S., Oliver, B., Petrill, S. A., Richardson, V., Rutter, M., . . Plomin, R. (1998). The validity of parent-based assessment of the cognitive abilities of 2-year-olds. British Journal of Developmental Psychology, 16, 349-363.

Saunders, J. B., Aasland, O. G., Babor, T. F., de la Fuente, J. R., \& Grant, M. (1993). Development of the Alcohol Use Disorders Identification Test (AUDIT): WHO collaborative project on early detection of persons with harmful alcohol consumption-II. Addiction, 88, 791-804.

Silberg, J. L., Maes, H., \& Eaves, L. J. (2010). Genetic and environmental influences on the transmission of parental depression to children's depression and conduct disturbance: An extended Children of Twins study. Journal of Child Psychology and Psychiatry, 51, 734-744.

Skevington, S. M., Lotfy, M., \& O'Connell, K. A. (2004). The World Health Organization's WHOQOL-BREF quality of life assessment: Psychometric properties and results of the international field trial. A report from the WHOQOL group. Quality of Life Research, 13, 299-310.

Spitzer, R. L., Kroenke, K., Williams, J. B. W., \& Löwe, B. (2006). A brief measure for assessing generalized anxiety disorder: The GAD-7. Archives of Internal Medicine, 166, 1092-1097.

Stringaris, A., Goodman, R., Ferdinando, S., Razdan, V., Muhrer, E., Leibenluft, E., \& Brotman, M. A. (2012). The affective reactivity index: A concise irritability scale for clinical and research settings. Journal of Child Psychology and Psychiatry, 53, 1109-1117.

Trouton, A., Spinath, F. M., \& Plomin, R. (2002). Twins Early Development Study (TEDS): A multivariate, longitudinal genetic investigation of language, cognition and behavior problems in childhood. Twin Research and Human Genetics, 5, 444-448.

Vidal, S. I., Vandeleur, C., Rothen, S., Gholam-Rezaee, M., Castelao, E., Halfon, O., .. Preisig, M. (2012). Risk of mental disorders in children of parents with alcohol or heroin dependence: A controlled high-risk study. European Addiction Research, 18, 253-264.

Winstanley, A., \& Gattis, M. (2013). The baby care questionnaire: A measure of parenting principles and practices during infancy. Infant Behavior \& Development, 36, 762-775. 